\title{
THE USE OF MANGANESE SUBSTITUTED \\ FERROTITANIUM ALLOYS FOR ENERGY STORAGE*
}

\author{
by
}

J. R. Johnson and J. J. Reilly

Brookhaven National Laboratory

Department of Energy and Environment

Division of Molecular Sciences

Upton, New York 11973

$\mathrm{U} \circ \mathrm{S} . \mathrm{A}$.

\author{
For publication in: \\ Proceedings of the International Conference \\ on Alternative Energy Sources \\ Miami Beach, Florida \\ December 5-7, 1977
}

*Work performed under the auspices of the U.S. Department of Energy. 


\title{
THE USE OF MANGANESE SUBSTITUTED FERROTITANIUM ALLOYS FOR ENERGY STORAGE*
}

\author{
J. R. Johnson and J. J. Reilly \\ Brookhaven National Laboratory \\ Upton, New York, U.S.A.
}

\section{ABSTRACT}

Metal hydrides provide an attractive means of energy storage for a variety of applications. Titanium iron hydride, to date, has received the most attention and shown the most potential. The physio-chemical characteristics of this hydride can be altered by the substitution of a third transition metal, such as manganese, yielding alloy-hydrogen systems with a wide range of properties. This allows hydride materials to be "tailor made" for a particular application.

Experimental results are presented and discussed in areas dealing with properties of major practical importance in the utilization of manganese substituted ferrotitanium alloys as hydrogen storage media. These areas encompass the following: (1) pressure-composition-temperature characteristics, (2) particle attrition properties, (3) effects of long-term cycling on alloy stability, (4) ease of activation and reactivation, and (5) effects of contaminants on alloy activity. In addition, the advantages and disadvantages regarding the use of ternary alloys vis-a-vis titanium iron will be discussed, as will the development of an optimum ternary alloy for use with a particular peak shaving option, i.e., the regenerative $\mathrm{H}_{2}-\mathrm{Cl}_{2}$ system.

\section{INTRODUCTION}

Many metal alloys react directly and reversibly with hydrogen gas at ambient temperatures and reasonable pressures to form solid hydride compounds [1-9]. Certain of these materials have become a focus of attention in the past few years because of their potential as energy storage media. A multitude of applications have been suggested for such compounds, both mobile and

*Work performed under the auspices of the U.S. Department of Energy. 
stationary in nature. Most of the proposed applications of these alloy-hydrogen systems derive their attractiveness from comparison to the conventional storage of hydrogen as a compressed gas or a cryogenic liquid and in comparison to competing energy storage options such as batteries [10-12]. Ultimately the advantages or disadvantages of the metal hydride energy storage compounds are directly related to their physio-chemical properties.

To date, the metal hydride which has received the most attention and shown the most potential for practical application has been titanium iron hydride. This has resulted principally from its favorable pressure-composition characteristics, production costs and the relative abundance of the starting materials. This metal-hydrogen system was discovered and characterized at Brookhaven National Laboratory (BNL) [1] and an engineering scale reservoir containing this material was constructed at BNL for use by Public Service Electric and Gas Company (PSE\&G) of New Jersey. It was combined with a water electrolyzer and fuel cell unit as a demonstration of a load leveling application [13]. The unit has been operated successfully over 60 charge-discharge cycles and is currently on loan to BNL. With respect to mobile applications, several organizations have converted a variety of vehicle types for operation with hydrogen derived from titanium iron hydride beds [14-16].

As has been noted previously [17], titanium iron hydride is not the ideal storage material for use in all applications and the ability to modify its properties is desirable. Changes in the properties of titanium iron hydride, as well as certain other hydrides, may be affected by the addition of small amounts of other components [18], by variation in the atom ratio of titanium and iron in the starting alloy $[1,17]$ or by the partial substitution or addition of another transition metal for iron resulting in a ternary alloy of general composition $\mathrm{TiFe}_{\mathrm{X}} \mathrm{M}_{\mathrm{y}}$ [17]. The effects of variation in the starting iron/titanium ratio and partial substitution of a third transition metal for iron are shown in Figs. 1 and 2. The partial substitution of iron by another transition metal makes it possible to "tailor make", to a high degree, an alloy with appropriate properties for particular energy storage and conversion applications.

In a previous paper [17], the integration of such ternary alloys with energy storage systems, their relative advantages, and also some general properties, mainly pressure-composition characteristics, were discussed. It is the purpose of this paper to 
discuss certain physio-chemical properties of a specific class of ternary $\mathrm{TiFe}_{\mathrm{X}} \mathrm{M}_{\mathrm{y}}$ alloys where $\mathrm{M}=$ manganese. The properties to be discussed are all of practical importance in the utilization of these solid hydrides as energy storage media and are as follows: (1) pressure-composition characteristics including hysteresis phenomena, (2) particle attrition as a function of cycling (hydriding-dehydriding), (3) ease of initial activation (hydriding for the first time) and subsequent reactivation after contamination, (4) effects of poisons on activity, and (5) effects of long-term cycling on the reversibility of the absorption-desorption reaction. Such properties were also of particular importance to a current program at BNL concerned with the development of an electrochemically regenerative hydrogen-chlorine system for energy storage. The development of an optimum hydride storage compound for use with this HCl system will also be discussed in relation to the overall reference design conditions for the unit.

The use of manganese as a substituent is particularly attractive since the metal is relatively inexpensive ( $\$ 0.50-0.60 / 1 \mathrm{~b})$ and abundant. Cost increases on the order of 3-4 percent could be expected for ternary alloys with 15 wt \% manganese. This is considered a small price to pay for the flexibility and increase in performance gained by such a substitution.

\section{EXPERIMENTAL}

Alloy samples used in these studies were prepared with starting metals of at least 99.9 percent purity. All materials were melted in an arc furnace under an inert gas atmosphere except those designated as INCO samples which were prepared at the International Nickel Company either by vacuum induction melting in graphite crucibles or air melting in clay-graphite crucibles followed by mischmetal* deoxidation [20]. The INCO samples were prepared as large melts and should be representative of commercially available alloys. The compositions indicated for the alloys are nominal values except for the INCO samples whose compositions have been determined by elemental analyses. The nominal compositions however should not deviate appreciably from the actual compositions sought since in the melting procedure extra

*Mischmetal is a low cost $(\$ 3.50 / 1 \mathrm{~b})$ alloy of various rare earth elements, comprising 48-50 wt \% Ce, 32-34\% La, 13-19\% Nd, 4-5\% Pr, and $\sim 1.5 \%$ others. 
manganese (the most volatile component of the alloys) was added to melts to compensate for any loss upon melting. None of these alloys were homogenized or annealed unless specifically indicated.

The laboratory apparatus and procedure for investigating pressure-composition properties of metal hydrides has been described in detail previously $[1,19]$. The same system was used in determining minimum initial activation conditions for all samples. The poisoning and particle attrition experiments were carried out on a cycling system built primarily to investigate changes in the activity (absorption-desorption properties) of alloys toward pure hydrogen as a function of the number of hydriding-dehydriding cycles. This cycling apparatus has three experimental stations attached to a pressure-vacuum manifold. A schematic of one such station including a standard sample reactor is shown in Fig. 3. The reactor for cycling experiments is essentially the standard high pressure reactor used in pressure-composition experiments which had been jacketed with 1-inch O.D. stainless steel tubing to allow heating and cooling of the samples. The inlet-outlet ports for the heat transfer fluids were connected by 0.25-inch copper tubing to two sets of time operated solenoid valves. One set of these valves operates in the cooling (hydriding) mode whereas the other allows for heating (dehydriding). These solenoid valves are in turn connected to two circulating constant temperature baths operated at $\sim 0^{\circ}$ and $100^{\circ} \mathrm{C}$. The elapsed time for each half cycle (heating or cooling) is approximately six minutes yielding a total cycle time of 12 minutes. This system is operated continuously which results in a total of 120 cycles per day. The remainder of the apparatus consists of a reservoir of calibrated volume ( $500 \mathrm{ml})$ attached by a 0.25 -inch stainless steel line also of known volume. The pressure is recorded using a 0-1000 psia Dynisco pressure transducer connected to a dual pen Honeywell Electronik 196 chart recorder. The temperature is measured by a thermocouple in the bottom of the reactor and is recorded as a second trace on the same recorder that monitors pressure. A sample or the entire station can be isolated from the manifold by means of bellows-seal valves.

Minimum initial activation experiments were performed to ascertain the ease of activation of the alloys. Approximately 5-10 grams of an alloy was crushed and passed through a 20-mesh $(841 \mathrm{\mu m})$ standard screen then loaded into a high pressure reactor. The reactor was connected to the high pressure-vacuum manifold and evacuated to about $10^{-4} \mathrm{~mm}$ pressure for a period of time usually on the order of $0.5 \mathrm{hr}$ either with or without 
heating. In the former case the sample temperature was maintained with an electrical resistance furnace or constant temperature bath. In most instances the reactor was not heated or cooled but simply outgassed at room temperature. Samples were then exposed to hydrogen usually at $500 \mathrm{psia}$ (34 atm). The pressure was recorded as a function of time. The free gas volume and sample size in these experiments were such that changes of pressure not in excess of 30 psia were expected even if the alloys absorbed to their highest capacity. Upon completion of an experiment the samples were isolated from the remainder of the manifold, cooled to liquid nitrogen temperature, and evacuated. The hydrogen content was then determined by heating the sample to $450^{\circ} \mathrm{C}$ and measuring the amount of evolved gas. Residual hydrogen, that which did not evolve at $450^{\circ} \mathrm{C}$, was measured on a known amount of alloy by a thermal decomposition technique whereby the sample is heated to approximately $1000^{\circ} \mathrm{C}$.

Physical deterioration experiments (loss of sample activity with cycling) were accomplished by crushing the alloy samples and retaining a 5-10 gram portion which had been sieved through a 20mesh $(841 \mathrm{\mu m})$ screen. The material was then activated in the normal manner [l] and charged to a high $\mathrm{H} / \mathrm{M}$ ratio. It was subsequently connected to a position on the cycling apparatus. The free gas volume above the bellows-seal valve to the reactor was evacuated and hydrogen was admitted. The hydrogen used was gold label quality Matheson gas of a minimum 99.999 percent purity. The same hydrogen gas was used in each cycle. Once the gas volume had been pressurized the sample position was closed to the remainder of the system, the reactor valve opened and cycling was begin. The pressure swing on cycling could be adjusted, within certain limits, by varying the system pressure, the cycle time, and the change in temperature. The change in composition per cycle can be calculated by noting the maximum and minimum pressures $(\triangle P)$. Any essential changes in the properties of the samples, e.g., phase separation, were indicated by a change in $(\Delta P)$ per cycle.

Particle attrition (particle size reduction) investigations were done in the same manner with the exception that a 5-10 gram sample of alloy was screened to a size range of $-10 /+16$ (1200 to $2000 \mu \mathrm{m})$ and then rescreened after successively increasing numbers of cycles. Particle sizes smaller than 325 mesh $(44 \mu \mathrm{m})$ were not analyzed further. 
Poisoning experiments were performed using the same technique. The activated sample was isolated on the cycling apparatus and a mixture of hydrogen containing a specified amount of a contaminant was admitted into the large free gas volume above the reactor. The reactor valve was then opened and the cycling operation begun. Any change in activity could be readily noted by a change in $(\Delta P)$.

\section{RESULTS AND DISCUSSION}

\section{Pressure-Composition-Temperature Characteristics}

In a previous paper [17] the effects of substitution or addition of another transition metal on the pressure-composition isotherms of TiFe were presented. All such composition adjustments led to a metal-hydride system of increased thermodynamic stability (isotherm-pressures were shifted to lower pressures at comparable $\mathrm{H} / \mathrm{M}$ values and temperatures) and generally to the introduction of a distortion or sloping effect in the isotherms. Figs. 4-7 illustrate this occurrence for TiFe systems substituted with cobalt, chromium, copper, and molybdenum. The substitution of manganese is no exception to these general observations as has been illustrated in Fig. 2. It should be noted that as the content of $\mathrm{Mn}$ increases hydride stabilities increase and up to a composition corresponding to $\mathrm{TiFe}_{0.80} \mathrm{Mn}_{0.20}$ ( $\sim 11$ wt \% $\mathrm{Mn}$ ) no loss of hydrogen capacity occurs. However, upon increasing the manganese concentration of the alloy to TiFe $0.70^{\mathrm{Mn}} 0.30$ a slight loss of hydrogen capacity is evident. This undoubtedly results from a significant increase in the amount of a second phase, $\mathrm{Ti}(\mathrm{Fe}, \mathrm{Mn})_{2}$, present in the "as cast" alloy. Partial ternary phase diagrams for the Ti-Fe-Mn system for "as cast" and equilibrium compositions have been developed by Sandrock [20] and Murakami and Enjyo [21], and they should be consulted by the reader if further information is required.

The increase in stability of the manganese substituted ferrotitanium alloy-hydrides, as with other substituted hydrides, may be explained qualitatively in terms of a correlation developed by Lundin et al. $[22,23]$ and the "Rule of Reversed Stability" formulated by van Mal et al. [8]. The former correlation states that a linear relationship exists between the standard free energy of formation of a hydride (or logarithm of the plateau pressure) and the interstitial hole size of the metallic compound lattice. The larger the hole size or the atomic volume, the more stable will be the resulting hydride. The correlation 
for each structure type is different and must be established for each separately. The "Rule of Reversed stability" states that the more stable an intermetallic compound, the less stable will be its hydride. All the manganese alloys investigated do show an increase in cell lattice parameter [20], $a_{0}$, over that for TiFe and therefore may be expected to have larger interstitial hole volumes resulting in more stable hydride phases.

As a result of the foregoing, it should be possible to produce manganese substituted ferrotitanium hydrides with a wide range of pressure-composition properties which retain high hydrogen storage capacity. This capability adds a degree of flexibility to the TiFe system and is of practical importance since it permits one to "tailor make" a storage alloy for a particular application.

Many of these manganese systems exhibit sloping plateaus. In general this phenomena is composition dependent and results from non-equilibrium solidification effects. Such solidification processes arise from large differences in liquidus-solidus temperatures in the phase equilibria and may give rise to segregation within a single phase region (concentration gradients) or more generally to coring. This may be eliminated in many cases by homogenization-annealing of the starting intermetallic and such a case is shown for the TiFe $0.76^{\mathrm{Mn}} 0.13^{-\mathrm{H}_{\mathrm{X}}}$ system in Fig. 8 . The annealed sample was heat treated in a resistance furnace under an inert atmosphere for three days at $1000^{\circ} \mathrm{C}$ prior to hydriding. Of course, temperatures and hold times at temperature must be optimized individually for alloys of differing compositions.

Finally, it has been noted that hysteresis is reduced in the manganese systems. An example of this is depicted in Fig. 9 in comparison to TiFe. This effect constitutes an advantage for the use of these materials in certain applications since lower pressures are required to charge a sample to an equivalent $\mathrm{H} / \mathrm{M}$ value.

\section{Particle Attrition Studies}

Upon absorption and desorption of hydrogen the average particle size of an alloy material decreases. This may lead to packing of the hydride bed, in practical storage applications, large pressure drops in a flow through system, and solid-gas separation problems [24-26]. TABLE I illustrates the rate of particle size reduction for $\mathrm{TiFe}_{0.70^{\mathrm{Mn}}} 0.18$ (INCO \#I) versus that for $\mathrm{TiFe}$. The 
salient features to be noted here are that the rate of attrition of the manganese substituted ferrotitanium alloy occurs much faster than for TiFe and most of the attrition takes place in the first few cycles.

The rapid particle attrition rate of the "as cast" manganese alloys can be rationalized partially in terms of the microstructural properties of these materials as has previously been suggested [20]. The "as cast" alloys generally are not single phase materials and in some instances (the INCO samples) have been deoxidized using mischmetal thus introducing an added phase consisting of rare-earth oxides. Depending on the composition of the alloy the hydridable single phase $\mathrm{Ti}(\mathrm{Fe}, \mathrm{Mn})$ material can be accompanied by hydridable $\mathrm{Ti}$ solid solution, $\mathrm{Ti}(\mathrm{Fe}, \mathrm{Mn})_{2}$ and a small amount of rare-earth metal oxides. The presence of $\mathrm{Ti}$ solid solution results in the formation of $\mathrm{TiH}_{2}$ which facilitates wedge cracking of the other phases whereas all other extraneous phases present provide pathways or nucleation sites which also greatly increase the rate at which a virgin alloy can be activated.

Effects of Long-Term Cycling on Alloy Stability

Titanium iron hydride and analogous compounds are thermodynamically metastable with respect to the formation of $\mathrm{TiH}_{2}$ and $\mathrm{TiFe}_{2}$. A series of long-term cycling experiments were therefore conducted to investigate the long-term stability of TiFe and various manganese alloys. The results of a representative portion of the experiments are given in TABLE II. No change in the activity (deterioration) of any of these alloys was observed as a function of time over a large number of cycles $(20,000-30,000)$ as measured by the constancy of $\Delta(\mathrm{H} / \mathrm{Ti})$. Further, in the samples of $\mathrm{TiFe}$ there was no evidence for the formation of $\mathrm{TiH}_{2}$ or $\mathrm{TiFe}_{2}$ in the alloys during the course of the experiment as determined by $x$-ray diffraction analysis. The manganese alloys were not so analyzed, but since no deterioration in performance was observed, it is highly unlikely that any disproportionation or phase separation is occurring.

The prime reason that no deterioration (phase instability) was observed for the hydrogen cycled $\mathrm{TiFe}$ and $\mathrm{TiFe}_{\mathrm{X}} \mathrm{Mn}_{\mathrm{Y}}$ alloys is probably a direct consequence of a rather simple rule, relating the reaction of intermetallics with hydrogen, which is firmly based on thermodynamic and structural principles [27-29]. It may be stated as follows: 
If the metal atoms of an intermetallic compound are not mobile (as is the case in low temperature reactions) only hydride phases can result which are structurally similar to the starting intermetaliic compound.

These cycling experiments were carried out at low temperatures $\left(-1\right.$ to $100^{\circ} \mathrm{C}$ ) and therefore, although the alloy phases are metastable with respect to the formation of $\mathrm{TiH}_{2}$ and other phases, no disproportionation occurs because the metal atoms are not sufficiently mobile.

Ease of Initial Activation Studies

The activation (first complete hydriding) of pure TiFe is time consuming, requires pressures on the order of $65 \mathrm{~atm}$ and temperatures $\geq 300^{\circ} \mathrm{C}$. These conditions require the use of materials for hydride bed reservoirs which are expensive and involve stringent design constraints. Further, the alternative of activating the alloy in a separate vessel and subsequently transferring it to the reservoir is not attractive. Any simplifications in the activation procedure which would moderate the conditions necessary and reduce the time required are important since substantial reductions in costs could be obtained. Such simplifications can be realized by the use of ternary manganese substituted ferrotitanium alloys as all these materials studied, to date, activate much more easily than TiFe as shown in TABLE III.

The percent reaction is a measure of hydrogen content actually attained versus the maximum possible under the conditions specified. It is likely that the same properties which result in an increased rate of particle attrition, as discussed above, are also responsible for the ease with which such alloys can be activated.

\section{Effects of Contaminants on Activity}

The question of the effect of contaminants in hydrogen gas streams on the absorption-desorption properties of metal-hydrogen systems is of practical importance for all potential applications of these materials. A portion of the hydride materials development program at BNL has been concerned with this problem. The contaminants of interest are these commonly occurring gases: $\mathrm{O}_{2}, \mathrm{CO}_{2}, \mathrm{~N}_{2}, \mathrm{H}_{2} \mathrm{O}(\mathrm{g})$, etc. In addition chlorine was of interest because an ongoing program at BNL is involved with the development of a regenerative $\mathrm{HCl}$ system for energy storage which 
utilizes a metal hydride as the hydrogen storage medium [30-34]. Results of the poisoning experiments are given in TABLES IV and $\mathrm{V}$. TiFe is seen to be very sensitive to oxygen and even as little as $10 \mathrm{ppm} \mathrm{O}_{2}$ in hydrogen has a detectable effect on the alloy activity. Also, higher concentration levels result in faster poisoning. The TiFe alloy, however, could be reactivated by standard techniques even at the highest $\mathrm{O}_{2}$ levels investigated.

The chlorine contamination experiments show that at $10 \mathrm{ppm}$ there is no detectable effect over the short term with the manganese alloy but at higher concentrations there is an appreciable loss of activity. Also of importance is the observation that in the latter case the samples could not be completely reactivated which is in opposition to the oxygen findings. Both $\mathrm{Cl}_{2}$ and $\mathrm{O}_{2}$ may have transformed to $\mathrm{HCl}$ and $\mathrm{H}_{2} \mathrm{O}$ under the experimental conditions, however, whether this was the case is probably only of academic interest. We did not analyze the gaseous phase or the sample surfaces since our primary concern was of a more qualitative nature. Future experiments should be designed to determine the actual gas phase species, their concentration levels, and to study the effects of contaminants on the surface of the alloys.

Until more quantitative and fundamental studies are undertaken, as mentioned above, we can only speculate as to mechanisms of poisoning. All that can be said now is that it appears that active surface sites for hydrogen absorption-desorption reactions are being blocked by the contaminants, or their reaction products such as $\mathrm{H}_{2} \mathrm{O}$ and $\mathrm{HCl}$. The formulation of hydrogen storage alloys which are not easily poisoned is very desirable but will probably require an understanding of the mechanism which obtains at the surface-gas interface.

Design of an Optimum TiFe $\mathrm{Xn}$. Alloy for a Regenerative $\mathrm{HCl}$ Energy Storage System

The use of metal-hydrides as energy storage media in conjunction with an electrolyzer and fuel cell for utility peak shaving applications has been an area of active interest at BNL for the past several years. An alloy with appropriate storage properties for use with a water electrolyzer-fuel cell unit has previously been designed [17]. The composition of the ternary alloy for this application corresponded to TiFeo.70 $\mathrm{Mn}_{0.20}$. Implementation of a large-scale unit employing the above components, however, is not being pursued because of its unfavorable 
economics. A potentially more cost effective and efficient energy storage system for utility load leveling applications is currently under development. The proposed system consists of a General Electric solid polymer electrolytic cell, metal hydride hydrogen storage, and liquid chlorine/hydrochloric acid storage subsystem [33]. In the storage mode, hydrogen and chlorine are produced and stored. In the discharge mode the hydrogen and chlorine are recombined in the same cell producing electric energy. The waste heat from the recombination reaction is used to supply heat of decomposition for the hydride. Reference design conditions for the development of a hydride storage subsystem for the unit specify a maximum hydrogen charging pressure of $500 \mathrm{psia}(34 \mathrm{~atm})$ at $40^{\circ} \mathrm{C}$, discharge to $45 \mathrm{psia}$ (3 atm) at $60^{\circ} \mathrm{C}$ and a storage capacity of $\geq 1.5$ wt \%. It is also required that the hydride be capable of attaining saturation in a period of five hours. A number of ternary alloys were formulated to meet these ctiteria as shown in TABLES VI and VII. The alloy with the optimum properties, to date, is one having the

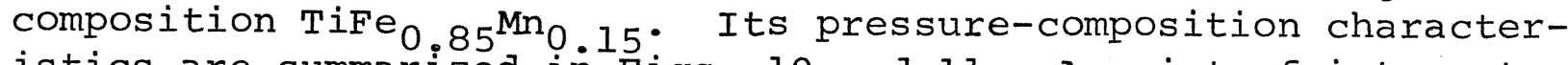
istics are summarized in Figs. 10 and 11 . A point of interest is that the hysteresis for this material is considerably reduced compared to the titanium iron-hydrogen system. This is significant since a reduction in the reference design charging pressure would lead to a yet larger difference in the maximum hydrogen storage capacity between $\mathrm{TiFe}_{0.85^{\mathrm{Mn}}} \mathrm{H}_{.15}$ and $\mathrm{TiFe}$.

\section{CONCLUSIONS}

The ability to "tailor make" a substituted ferrotitanium alloy hydride with properties matched to a particular storage application extends greatly the versatility of such metal-hydrogen systems for future use. Although much work remains to be done in defining and understanding the properties of these potentially attractive metal-hydrogen systems, we have tried to present here a cross-section of investigations in areas of practical importance which should be considered in any present or future use of such materials. 


\section{ACKNOWLEDGEMENTS}

The authors wish to express their gratitude to S. Bookless, A. Holtz, and $J$. Hughes for their expert technical assistance in the laboratory. Also, we would like to express our thanks to G. Sandrock of the International Nickel Company for his advice and assistance in matters of a metallurgical nature.

\section{REFERENCES}

I. Reilly, J. J. and Wiswall, R. H., Jr., Formation and Properties of Iron Titanium Hydride, Inorg. Chem. 13, 218 (1974).

2. Pebler, A. and Gulbransen, E. A., Equilibrium Studies on the Systems $\mathrm{ZrCr}_{2}-\mathrm{H}_{2}, \mathrm{ZrV}_{2}-\mathrm{H}_{2}$, and $\mathrm{ZrMO}_{2}-\mathrm{H}_{2}$ Between $\mathrm{O}$ and $900^{\circ} \mathrm{C}$, Trans. TMS-AIME, 239, 1593 (1967).

3. Yamashita, T., Gamo, T., Moriwaki, Y., and Fukuda, M., Hydride Formation of Ti-Mn Binary Alloys, J. Jap. Inst. of Metals, 41, No. 2, 148 (1977).

4. Ishido, Y., Nishimiya, N., and Suzuki, A., Preparation and Equilibrium study on Zirconium Manganese Hydride $\left(\mathrm{ZrMn}_{2} \mathrm{H}_{\mathrm{X}}\right)$, Denki Kagaku, 45, No. 1, 52 (1977).

5. Machida, Y., Yamadaya, T., and Asanuma, M., Hydride Formation of Cl4-Type Ti Alloys, pres. in part at the International Symposium on Hydrides for Energy Storage, Geilo, Norway, August 1977.

6. Sandrock, G. D., A New Family of Hydrogen storage Alloys Based on the System Nickel-Mischmetal-Calcium, Proceedings 12th IECEC, 1, 951, Washington, D.C., 1977.

7. Buschow, K.H.J. and van Mal, H. H., Phase Relations and Hydrogen Absorption in the Lanthanum-Nickel System, J. LessCommon Metals, 29, 203 (1972).

8. van Mal, H. H., Buschow, K.H.J., and Miedema, A. R., Hydrogen Absorption in $\mathrm{LaNi}_{5}$ and Related Compounds: Experimental Observations and Their Explanation, J. Less-Common Metals, 35, 65 (1974). 
9. van Vucht, J.H.N., Kuijpers, F. A., and Bruning, H.C.A.M., Reversible Room Temperature Absorption of Large Quantities of Hydrogen by Intermetallic compounds, Philips Res. Reports 25,133 (1970).

10. Reilly, J. J., Hydrogen: Its Technology and Implications, Vol。II, lst Ed., K. E. Cox and K. D. Williamson, Eds.. CRC Press, Cleveland, Ohio, 1977, Chapter 2.

11. Reilly, J. J., Applications of Metal Hydrides, pres. in part at the International Symposium on Hydrides for Energy Storage, Geilo, Norway, August 1977.

12. Reilly, J. J., Hoffman, K. C., Strickland, G., and Wiswall, R. H., Iron Titanium Hydride as a Source of Hydrogen Fuel for Stationary and Automotive Applications, 26th Annual Proceedings of Power Sources Conference, Atlantic City, New Jersey, May 1974.

13. Strickland, G., and Reilly, J. J., operating Manual for the PSE\&G Hydrogen Reservoir containing Iron Titanium Hydride, BNL 50421, February 1974.

14. Wolley, R. L. and Simons, H。 M., Hydrogen Storage in Vehicles--An operational Comparison of Alternative Prototypes, Proceedings of Fuels and Lubricants Meeting, St. Louis, Missouri, June 1976.

15. Buechner, H. and Saufferer, H., Results of Hydride Research and the Consequences for the Development of Hydride Vehicles, 4th International Symposium on Automotive Propulsion Systems, Arlington, Virginia, April 1977.

16. Dangerfield, J., Mass Transit in a Hydrogen Economy, Hydrogen Progress, 2nd Quarter 1977, Billings Energy Corporation, Provo, Utah.

17. Reilly, J. J. and Johnson, J. R., Titanium Alloy Hydrides, Their Properties and Applications, Proceedings of the lst World Hydrogen Energy Conference, Miami Beach, Florida, March 1976. 
18. Reilly, J. J. and Wiswall, R. H., The Effect of Minor Constituents on the Properties of Vanadium and Niobium Hydrides, Proceedings of the International Meeting on Hydrogen in Metals, Julich, Germany, March 1972.

19. Reilly, J. J. and Wiswall, R. H., The Reaction of Hydrogen with Alloys of Magnesium and Copper, Inorg. Chem. 6,2220 (1967).

20. Sandrock, G. D., The Interrelations Among Composition, Microstructure and Hydriding Behavior for Alloys Based on the Intermetallic Compound FeTi, Final Report, Contract BNL-352410S, June 1976.

21. Murakami, Y. and Enjyo, T., Investigation of Ti Rich Ti-Fe-Mn Alloy System on the Solid Equilibrium Relation in the Ti-Fe-Mn System, Nippon Kinzoku Gakkaishi 22, 329 (1958).

22. Lundin, C. E., Lynch, F. E., and Magee, C. B., Some Useful Relationships Between the Physical and Thermodynamic Properties of Metal Hydrides, Proceedings lith IECEC, State Line, Nevada, September 1976.

23. Lundin, C. E., Lynch, F. E., and Magee, C. B., to be published in J. Less-Common Metals.

24. Rosso, M. J., Jr., Strickland, G., and Milau, J. S., Pressure-Drop-Fluid-Flow Correlation for Fixed Beds of Small, Irregularly Shaped Particles, BNL 50589, November 1976.

25. Strickland, G., Some Observations on the Effects of the Volumetric Expansion of Iron Titanium on Vessels Built at BNL, BNL 23130, August 1977.

26. Strickland, G., State-of-the-Art Summary of the Technical Problems Involved in the storage of Hydrogen Via Metal Hydrides, pres. in part at the International Conference on Alternative Energy Sources, Miami Beach, Florida, December 1977.

27. Reilly, J. J., Johnson, J. R., and Reidinger, F., The Reactions of Hydrogen with Intermetallic Compounds, pres. in part at the 2nd Joint CIC-ACS Conference, Montreal, Canada, May-June 1977. 
28. Reilly, J. J., Synthesis and Properties of Useful Metal Hydrides: A Review of Recent Work at Brookhaven National Laboratory, pres. in part at the International Symposium on Hydrides for Energy Storage, Geilo, Norway, August 1977.

29. Johnson, J. R. and Reilly, J. J., The Metal Hydride Development Program at Brookhaven National Laboratory, pres. in part at the DOE Chemical Energy Storage and Hydrogen Energy Systems Contracts Review Meeting, Hunt Valley, Maryland, November 1977.

30. Gileadi, E., Srinivasan, S., Salzano, F. J. Braun, C., Beaufrere, A., Gottesfeld, S., Nuttall, L. J., and LaConti, A. B., J. Power Sources, in press.

31. Srinivasan, S., Yeo, R. S., and Beaufrere, A., The HydrogenHalogen Storage System: Preliminary Feasibility and Economic Assessment, BNL 22164, January 1977.

32. Beaufrere, A., Yeo, R. S., Srinivasan, S., McElroy, J., and Hart, G., A Hydrogen-Halogen Energy Storage system for Electric Utility Applications, Proceedings 12th IECEC, Washington, D. C.. 1977.

33. McBreen, J., Yeo, R. S., Beaufrere, A., Chin, D. T., and Srinivasan, S., The Hydrogen-Chlorine Energy Storage System, pres. in part at the DOE Chemical Energy storage and Hydrogen Energy systems Contracts Review Meeting, Hunt Valley, Maryland, November 1977.

34. Reilly, J. J. and Johnson, J. R., Metal Hydride Program at BNL--Current Status and Future Plans, Proceedings of the ERDA Contractors' Review Meeting on Chemical Energy Storage and Hydrogen Energy Systems, Airlie, Virginia, November 1976. 
TABLE I

PARTICLE SIZE DISTRIBUTION FOR TIFe $0.7^{\mathrm{Mn}} 0.18$ (INCO \#1) AND TIFe* AS A FUNCTION OF THE NUMBER OF HYDRIDING-DEHYDRIDING CYCLES

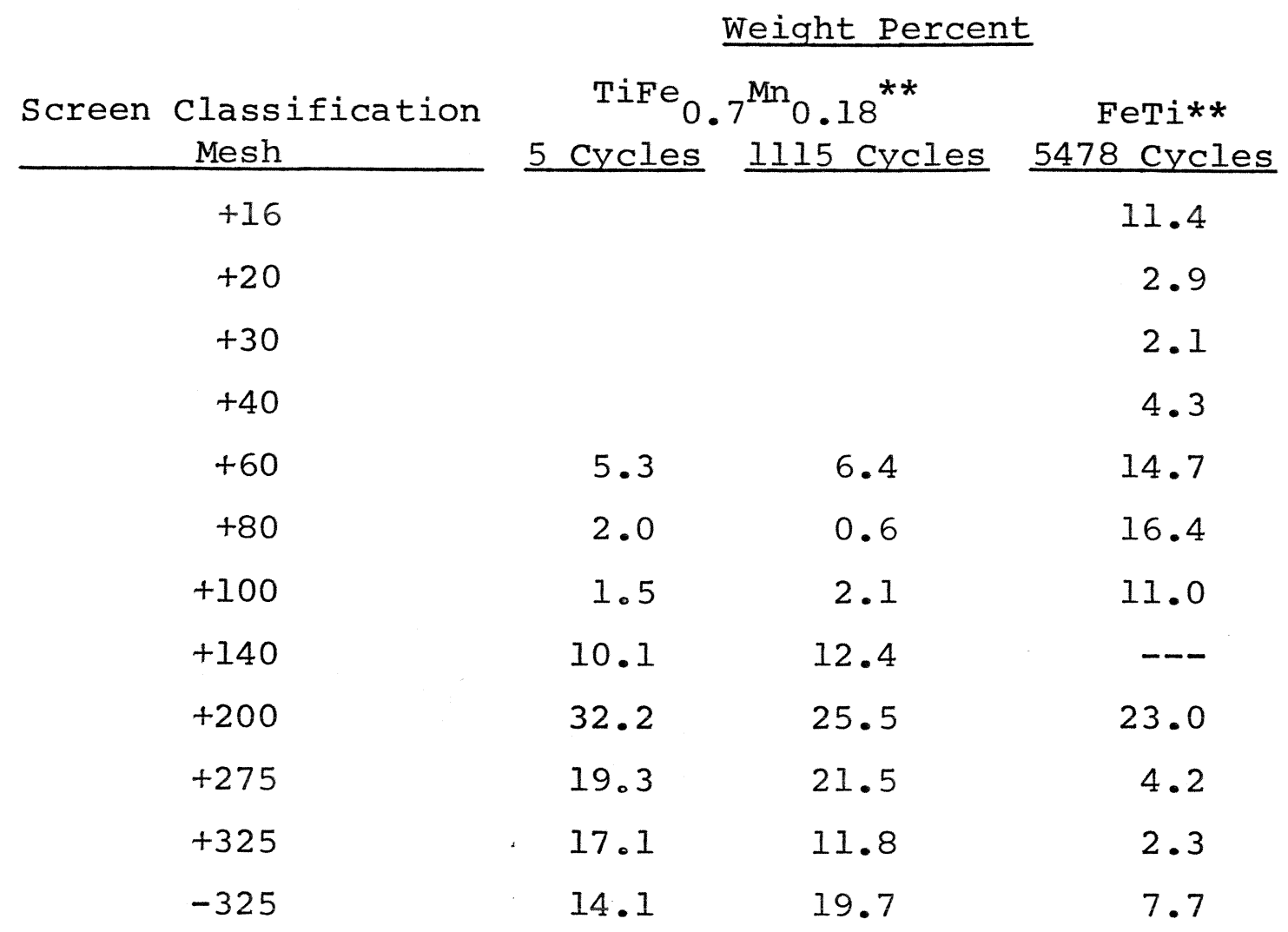

*Commercially obtained as a $500 \mathrm{lb}$. ingot. **Initial particle size range $-10 /+16$ (U.S. Standard Sieve). 
TABLE II

ACTIVITY OF TiFe AND TiFe $\mathrm{x}_{\mathrm{y}}$ ALLOYS IN $\mathrm{A}_{2}$ ENVIRONMENT AS A FUNCTION OF THE NUMBER OF HYDRIDING-DEHYDRIDING CYCLES

\begin{tabular}{|c|c|c|c|c|}
\hline $\begin{array}{c}\text { Alloy } \\
\text { Composition }\end{array}$ & $\begin{array}{c}\text { Number of } \\
\text { Cycles } \\
\end{array}$ & $\begin{array}{c}\text { Temperature } \\
\text { Change/Cycle } \\
\text { O, Avg. } \\
\end{array}$ & $\begin{array}{c}\text { Pressure } \\
\text { Change/Cycle } \\
\text { PSIA, Avg. } \\
\end{array}$ & $\begin{array}{c}\text { Composition } \\
\text { Change/Cycle } \\
\Delta(\mathrm{H} / \mathrm{Ti}) \\
\end{array}$ \\
\hline TiFe* & 19600 & -1 to +100 & $428-459$ & 1.11 \\
\hline $\begin{array}{c}\text { TiFe }_{0.79^{\mathrm{Mn}}} 0.15 \\
\text { (INCO \#2) }\end{array}$ & 28400 & -1 to +100 & $179-211$ & 1.08 \\
\hline TiFe $_{0.76^{\mathrm{Mn}} 0.14}$ & 26300 & -1 to +100 & $87-114$ & 0.96 \\
\hline
\end{tabular}

*Commercially obtained as a 500 lb. ingot. 
TABLE III

LOW TEMPERATURE ACTIVATION EXPERIMENTS FOR TIFe ${ }_{x}{ }_{y}$ ALLOYS

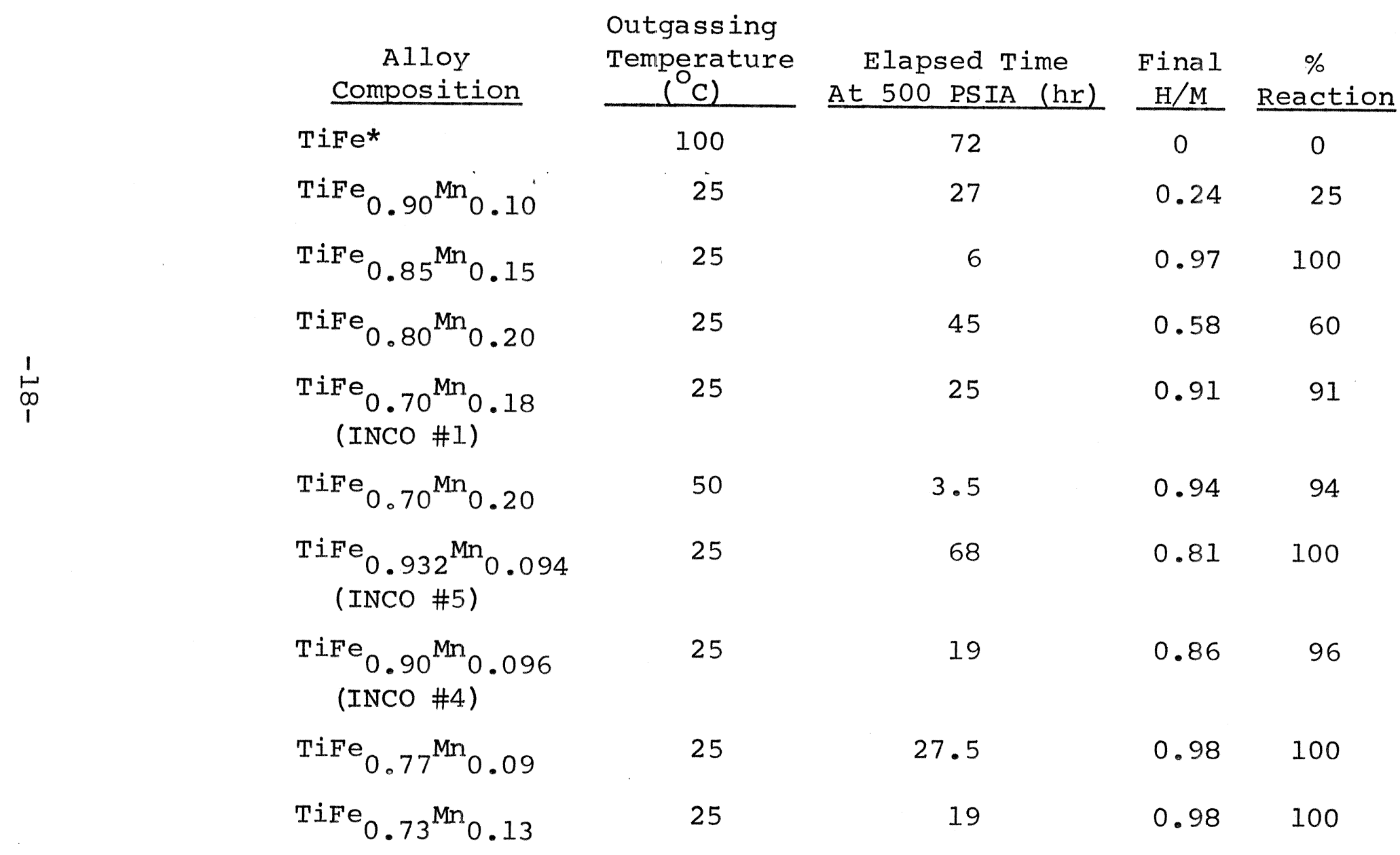

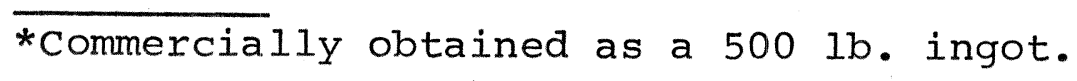




\section{TABLE IV}

EFFECT OF $\mathrm{O}_{2}$ IN $\mathrm{H}_{2}$ ON THE ACTIVITY OF
TiFe- $\mathrm{H}_{\mathrm{x}} *$

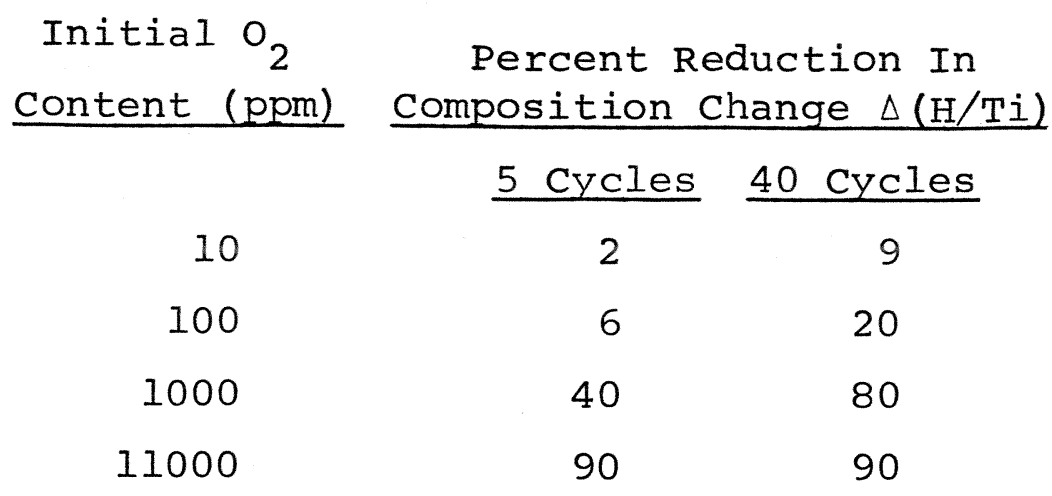

*Commercially obtained as a 500 lb. ingot.

TABLE V

EFFECT OF $\mathrm{Cl}_{2}$ IN $\mathrm{H}_{2}$ GAS ON THE ACTIVITY

OF TiFe $0.9^{\mathrm{Mn}} 0.1^{-\mathrm{H}_{\mathrm{X}}}$

Initial $\mathrm{Cl}_{2}$ Activity Reactivation Activity Content (ppm) Loss (\%) Temperature ( ${ }^{\mathrm{C}}$ ) Recovered (\%)

$\begin{array}{rrrr}10 & -- & --- & --- \\ 100 & 50 & 110 & 88 \\ 1000 & 75 & 110 & 63 * \\ 1000 & 75 & 300 & 75 * \\ & 400 & 75 *\end{array}$

*These are maximum values. After exposure to high $\mathrm{Cl}_{2}$ concentrations there was a slow deterioration in performance after reactivation. 
TABLE VI

HYDROGEN STORAGE CAPACITIES FOR TIFe ${ }_{x}{ }_{y}$ ALLOYS UNDER PROJECTED $\mathrm{H}_{2}-\mathrm{Cl}_{2}$ CELL OPERATING CONDITIONS

Alloy

Maximum $\mathrm{H}_{2}$

Composition Storage Capacity wt \%

TiFe*

1.55

TiFe $_{0.90^{\mathrm{Mn}}} 0.096$

1.50

( INCO \#4)

$\mathrm{TiFe}_{0.90^{\mathrm{Mn}}} 0.10$

1.65

$\mathrm{TiFe}_{0.85^{\mathrm{Mn}} 0.15}$

1.80

$\mathrm{TiFe}_{0.80^{\mathrm{Mn}}} 0.20$

1.60

$\mathrm{TiFe}_{0.70^{\mathrm{Mn}}} 0.30$

0.90

TiFe $_{0.932^{\mathrm{Mn}}} 0.094$

1.35

(INCO \#5)

*Commercially obtained as a 500 lb. ingot.

TABLE VII

CHARGING TESTS OF 5 HOURS DURATION FOR

COMPLETELY ACTIVATED TIFe $\mathrm{Mn}$ ALLOYS AT

500 PSIA AND $25^{\circ} \mathrm{C}$

\begin{tabular}{|c|c|c|}
\hline $\begin{array}{c}\text { Alloy } \\
\text { Composition }\end{array}$ & $\begin{array}{c}\text { Final } \\
\mathrm{H} / \mathrm{M} \\
\end{array}$ & $\begin{array}{c}\% \\
\text { Reaction } \\
\end{array}$ \\
\hline $\begin{array}{c}\mathrm{TiFe}_{0.93^{\mathrm{Mn}}} 0.094 \\
\text { (INCO \#5) }\end{array}$ & 0.81 & 100 \\
\hline TiFe $_{0.85^{\mathrm{Mn}} 0.15}$ & 0.98 & 100 \\
\hline
\end{tabular}


4 - NEGATIVE NUMBERS: NEGATIVE NUMBERS FOR FIGURES ARE:

\begin{tabular}{|c|c|c|c|c|c|c|}
\hline $\begin{array}{l}\text { FIG. NO. } \\
1\end{array}$ & $\begin{array}{l}\text { NEG. NO. } \\
1-614-73\end{array}$ & $\begin{array}{c}\text { FIG. NO. } \\
6 \\
6\end{array}$ & $\begin{array}{l}\text { NEG. NO. } \\
12-56-75\end{array}$ & $\begin{array}{c}\text { FIG. NO. } \\
11\end{array}$ & $\begin{array}{l}\text { NEG. NO. } \\
10-1572-77\end{array}$ & FIC \\
\hline 2 & $11-814-77$ & 7 & $12-47-75$ & & & \\
\hline 3 & $3-267-76$ & 8 & $11-816-77$ & & & \\
\hline 4 & $12-55-75$ & 9 & $1-324-76$ &. & & \\
\hline 5 & $12-45-75$ & 10 & $10-1571-77$ & & & \\
\hline
\end{tabular}




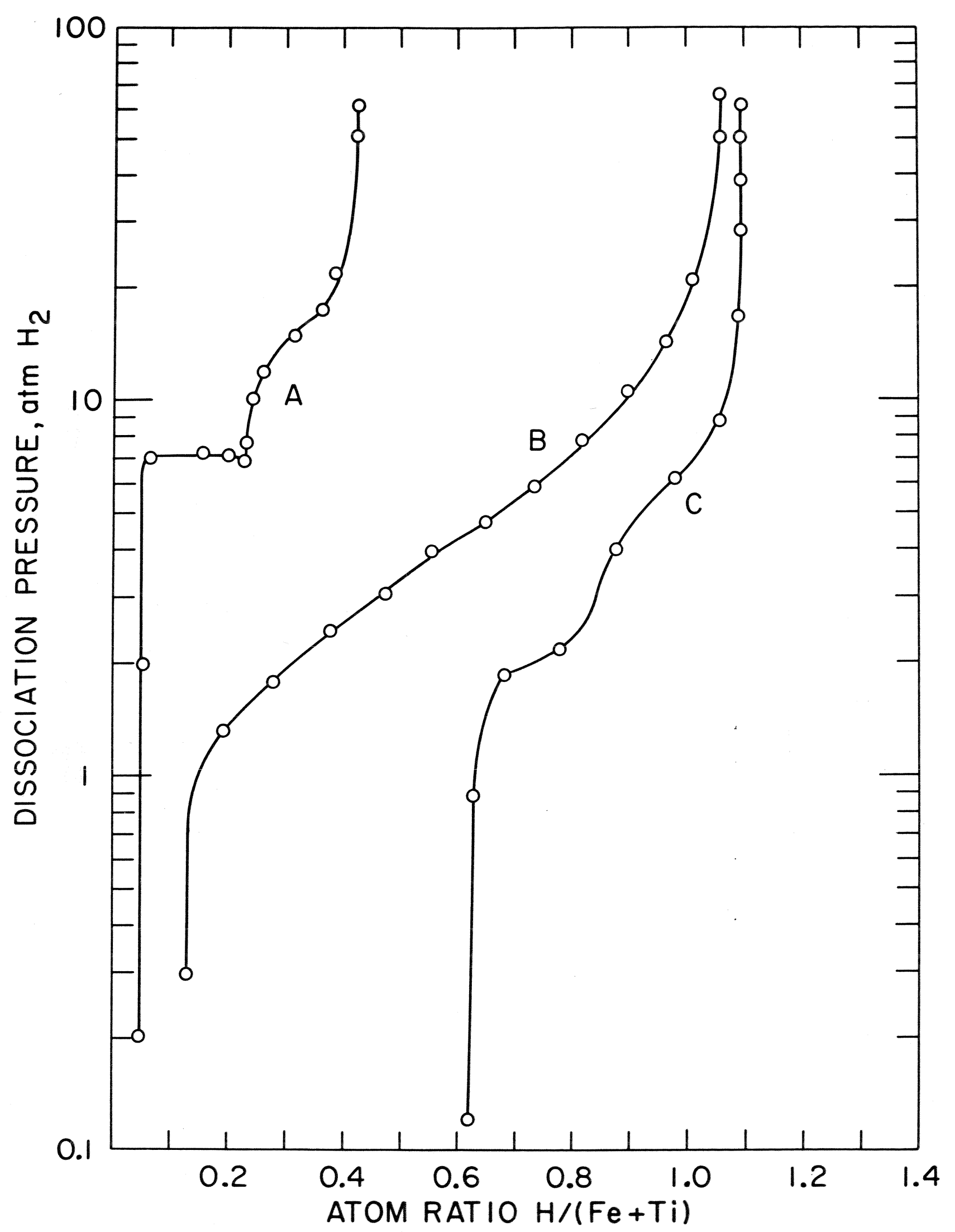

Fig. 1. Pressure-Composition Isotherms for Alloys of Various $\mathrm{Fe} / \mathrm{Ti}$ Ratios at $40^{\circ} \mathrm{C}:$ (A) 60.5 wt $\% \mathrm{Fe}, 39.5$ wt $\% \mathrm{Ti}$; (B) 50.5 wt $\% \mathrm{Fe}, 49.2$ wt $\% \mathrm{Ti}$; (C) 36.7 wt $\% \mathrm{Fe}, 63.2$ wt $\% \mathrm{Ti}$. 


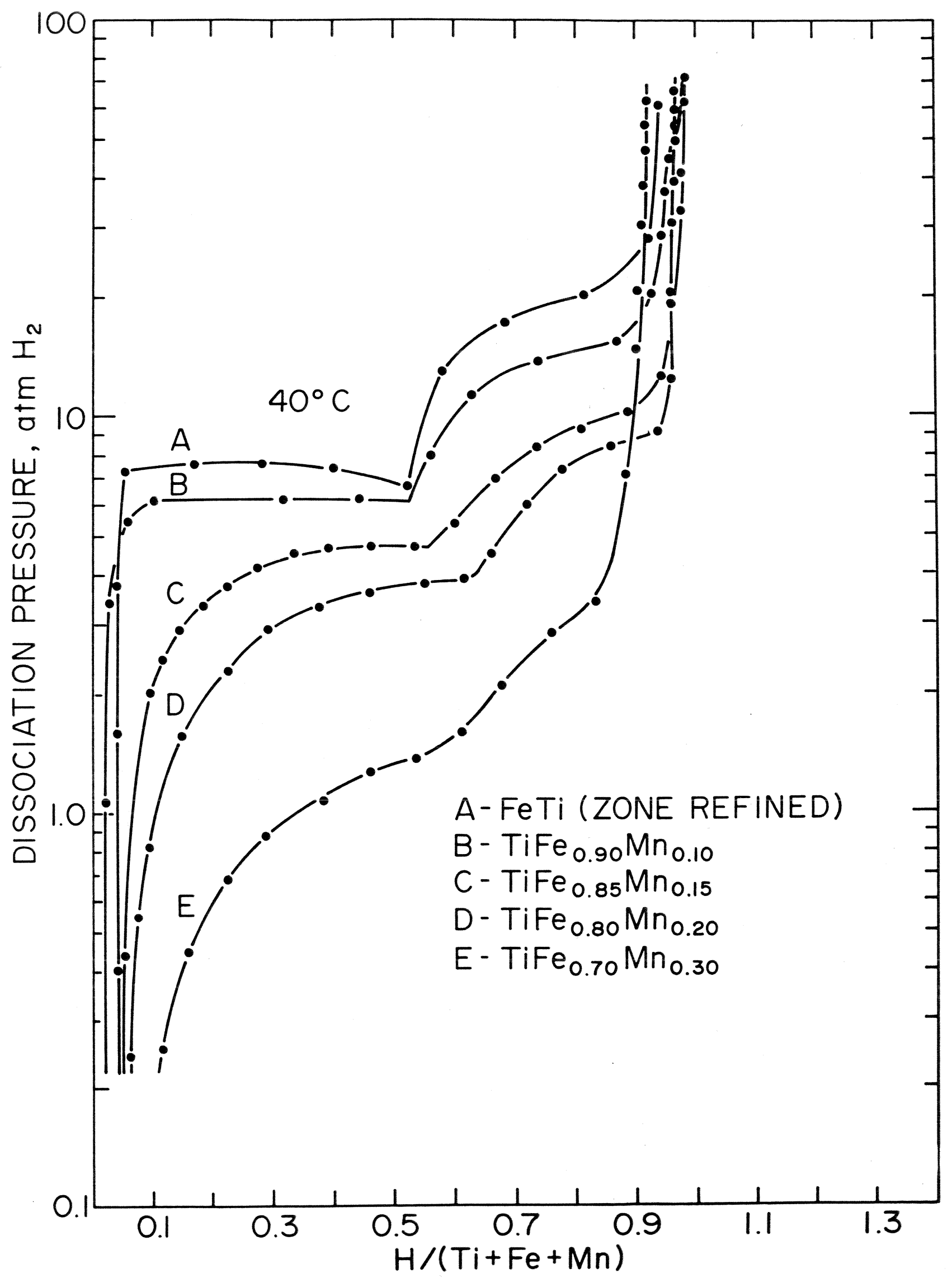

Fig. 2. Pressure-Composition Desorption Isotherms for FeTi Alloys of Various $\mathrm{Mn}$ Contents at $40^{\circ} \mathrm{C}$. 


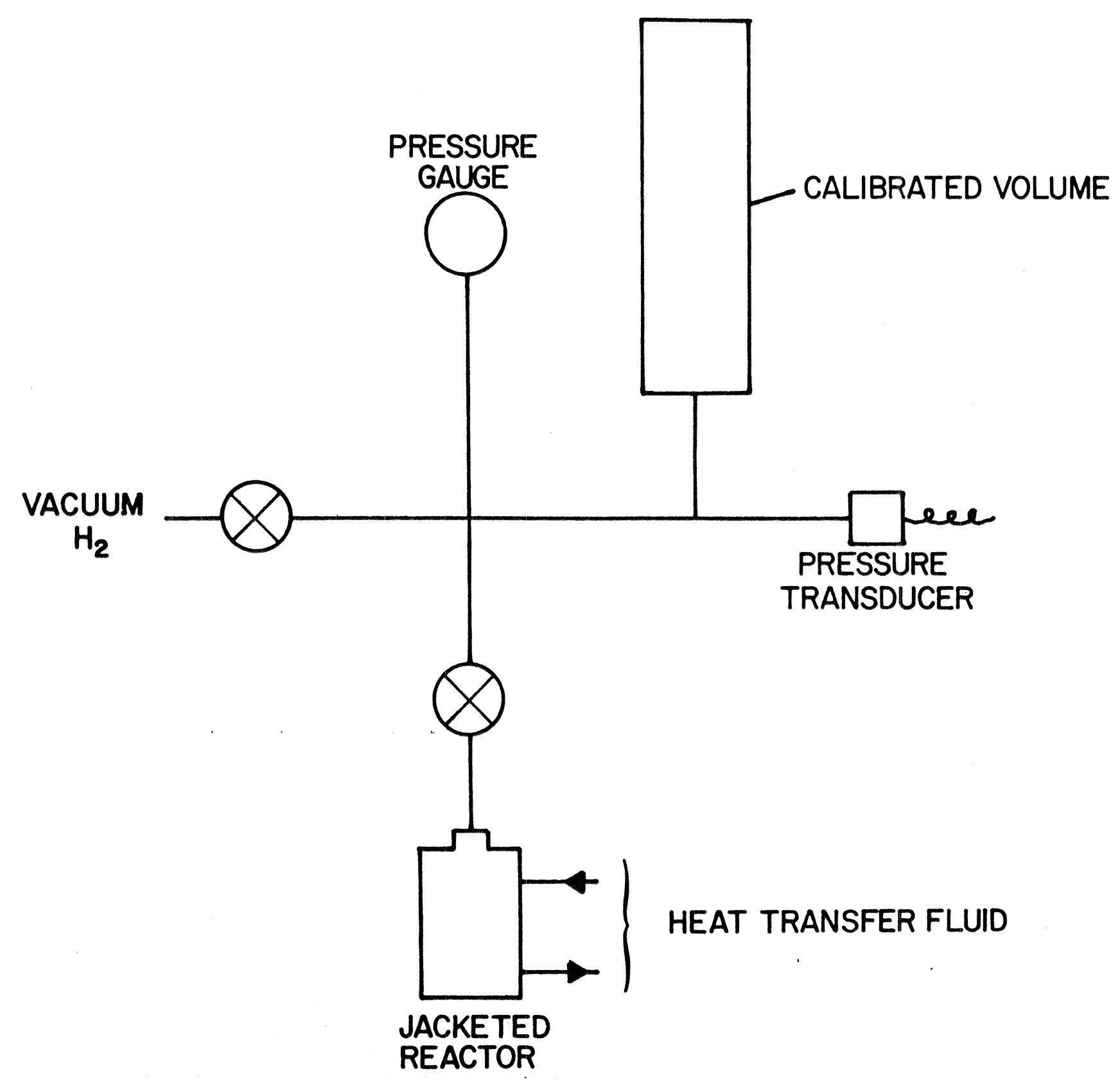

Fig. 3. Schematic of a Station on the High Cycle Test Apparatus. 


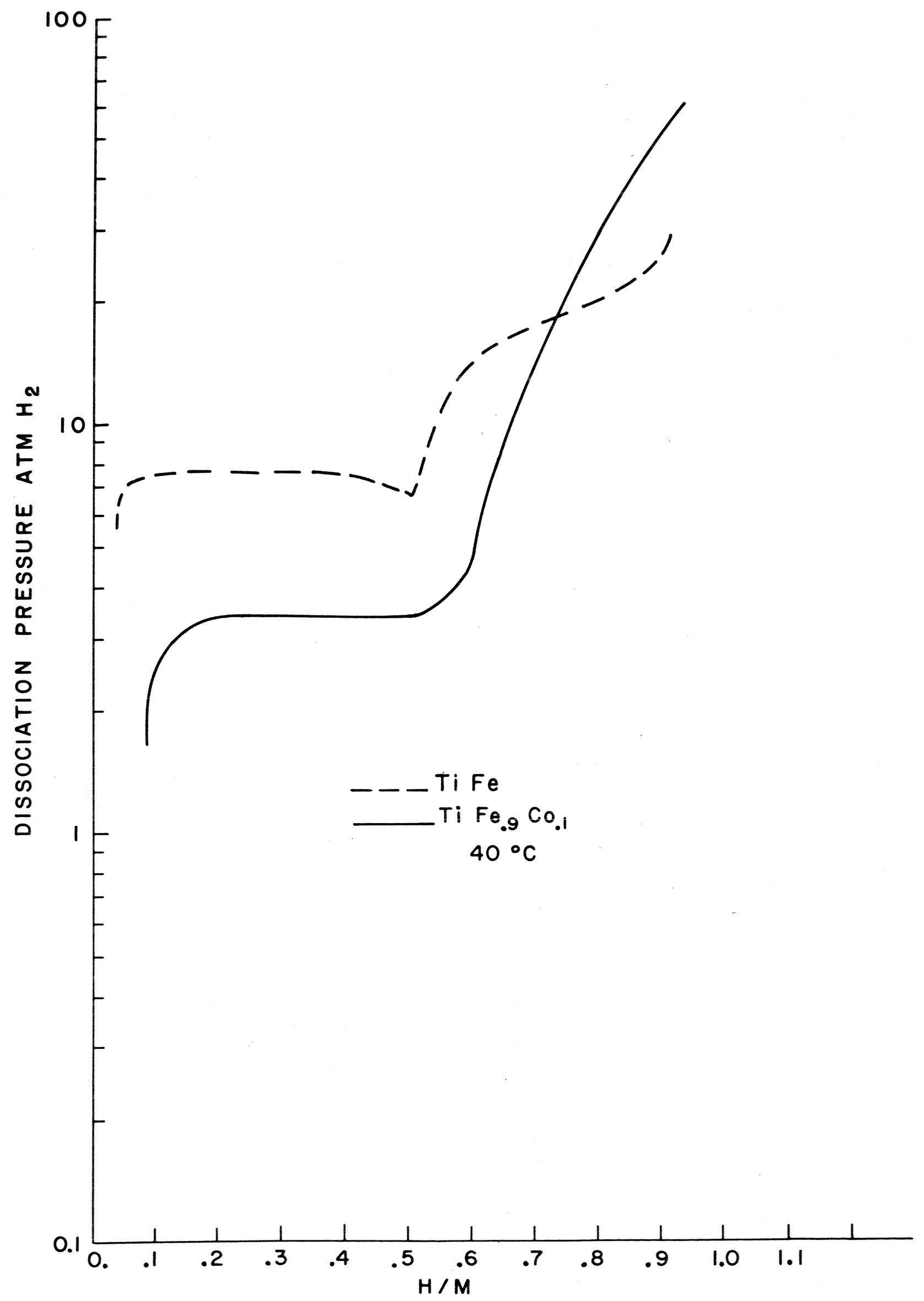

Fig. 4. A Comparison of $40^{\circ} \mathrm{C}$ Desorption Isotherms for the TiFe-H and $\mathrm{TiFe}_{0.9} \mathrm{CO}_{0.1^{-\mathrm{H}} \text { Systems. }}$ 


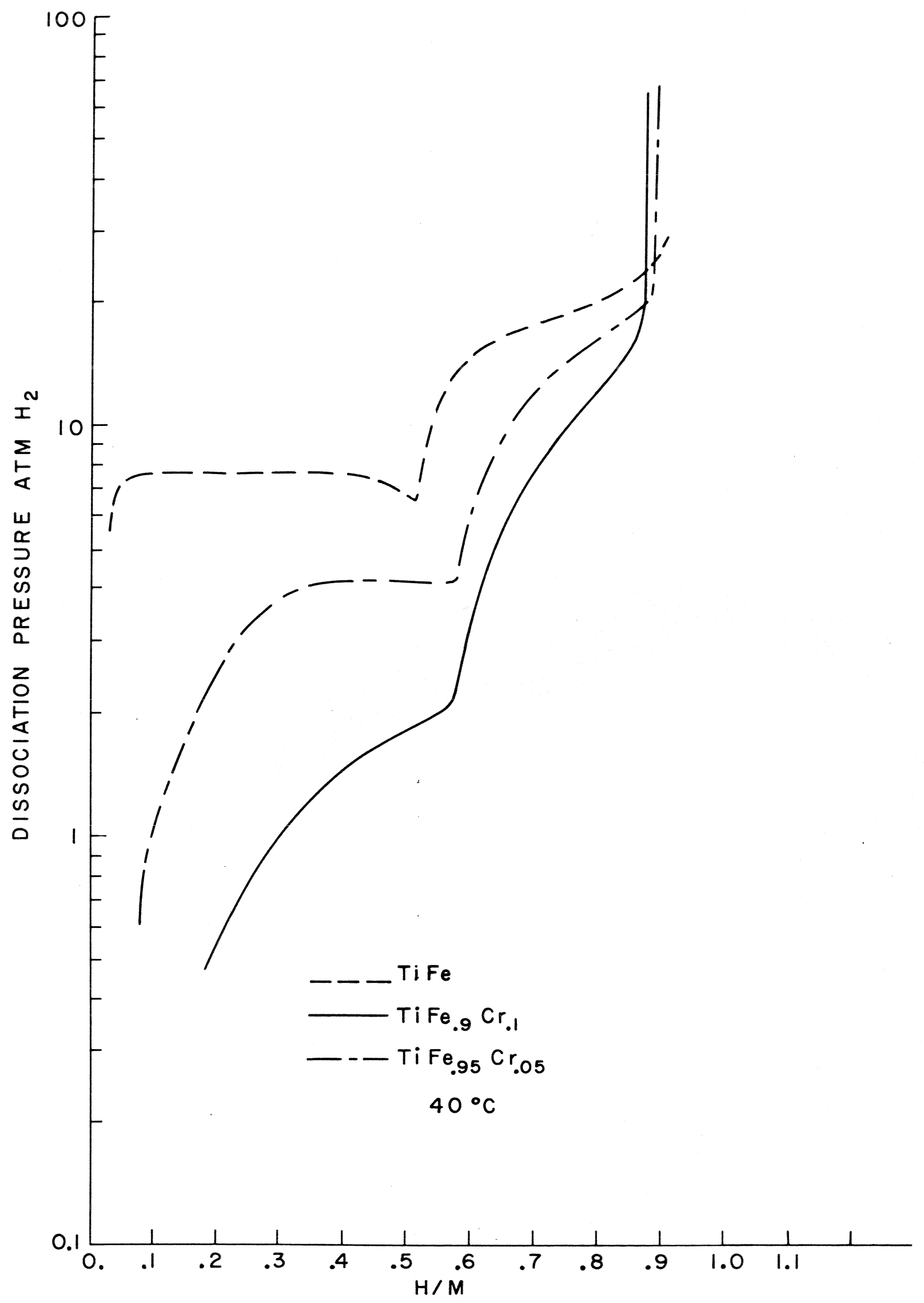

Fig. 5. A Comparison of $40^{\circ} \mathrm{C}$ Desorption Isotherms for the TiFe-H,

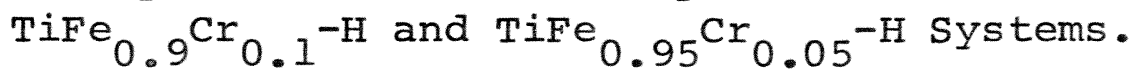




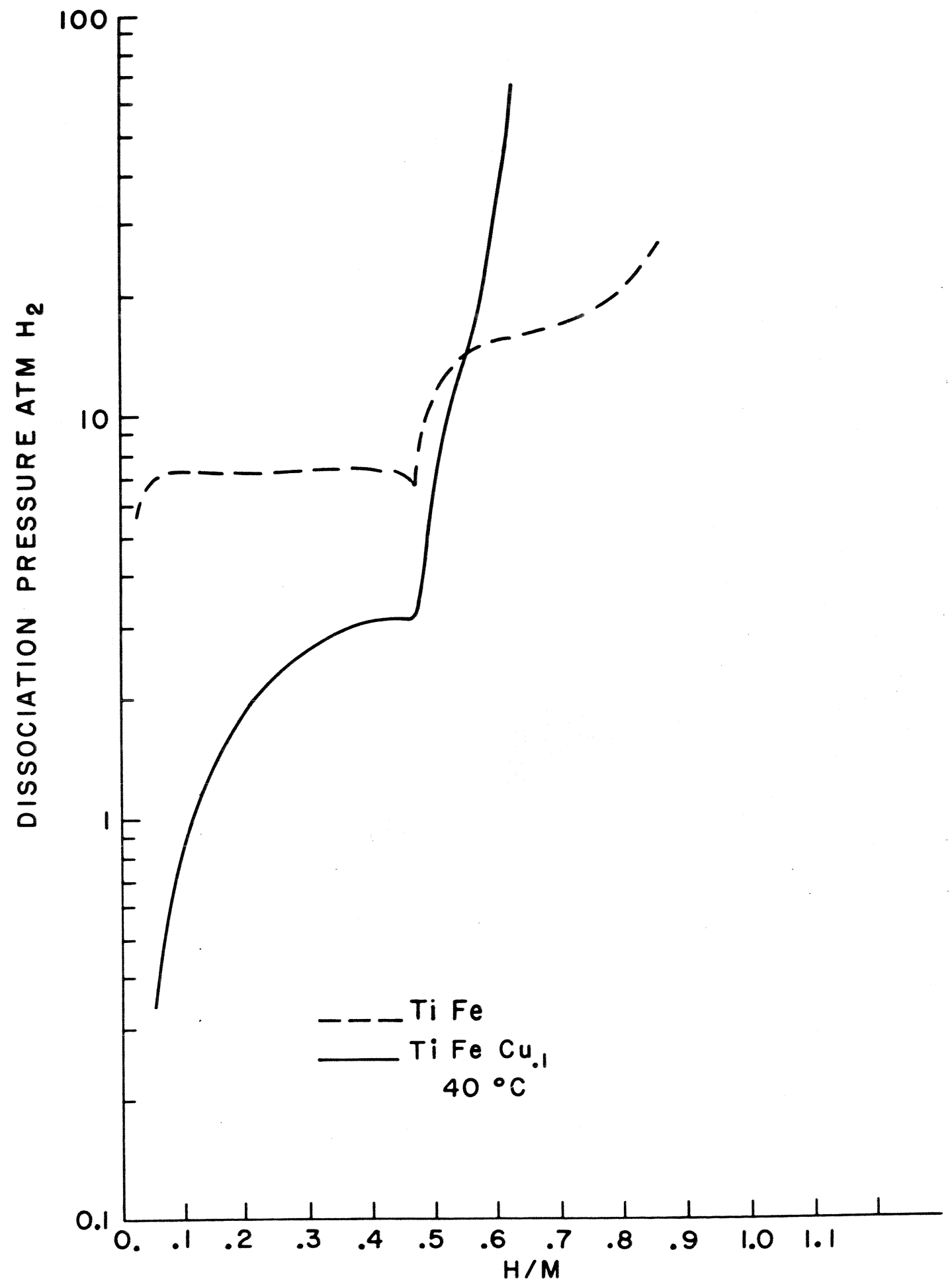

Fig. 6. A Comparison of $40^{\circ} \mathrm{C}$ Desorption Isotherms for the

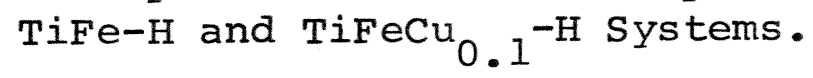




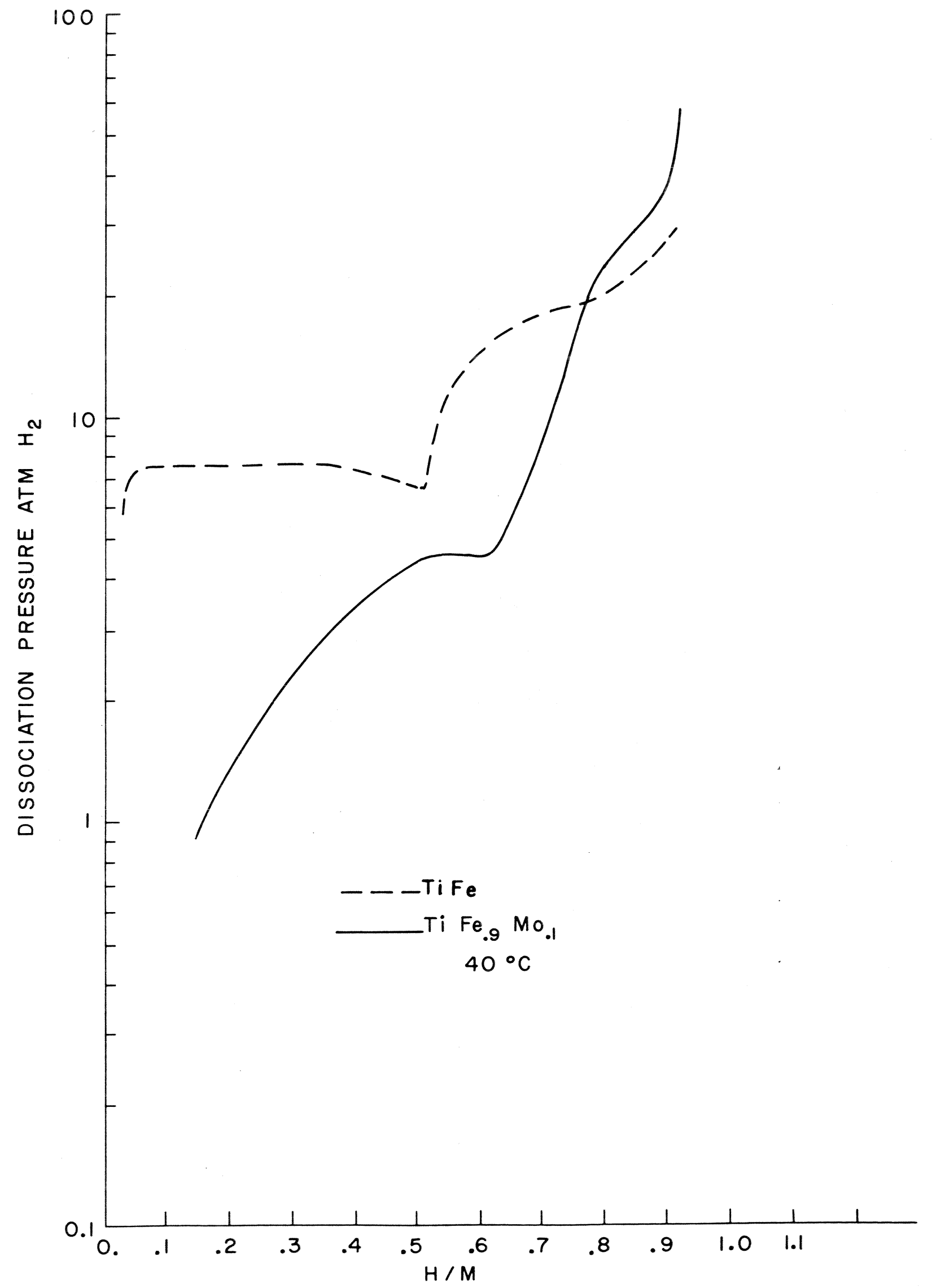

Fig. 7. A Comparison of $40^{\circ} \mathrm{C}$ Desorption Isotherms for the TiFe-H and $\mathrm{TiFe}_{0.9^{\mathrm{MO}}} \mathrm{I.1}^{-\mathrm{H}}$ Systems. 


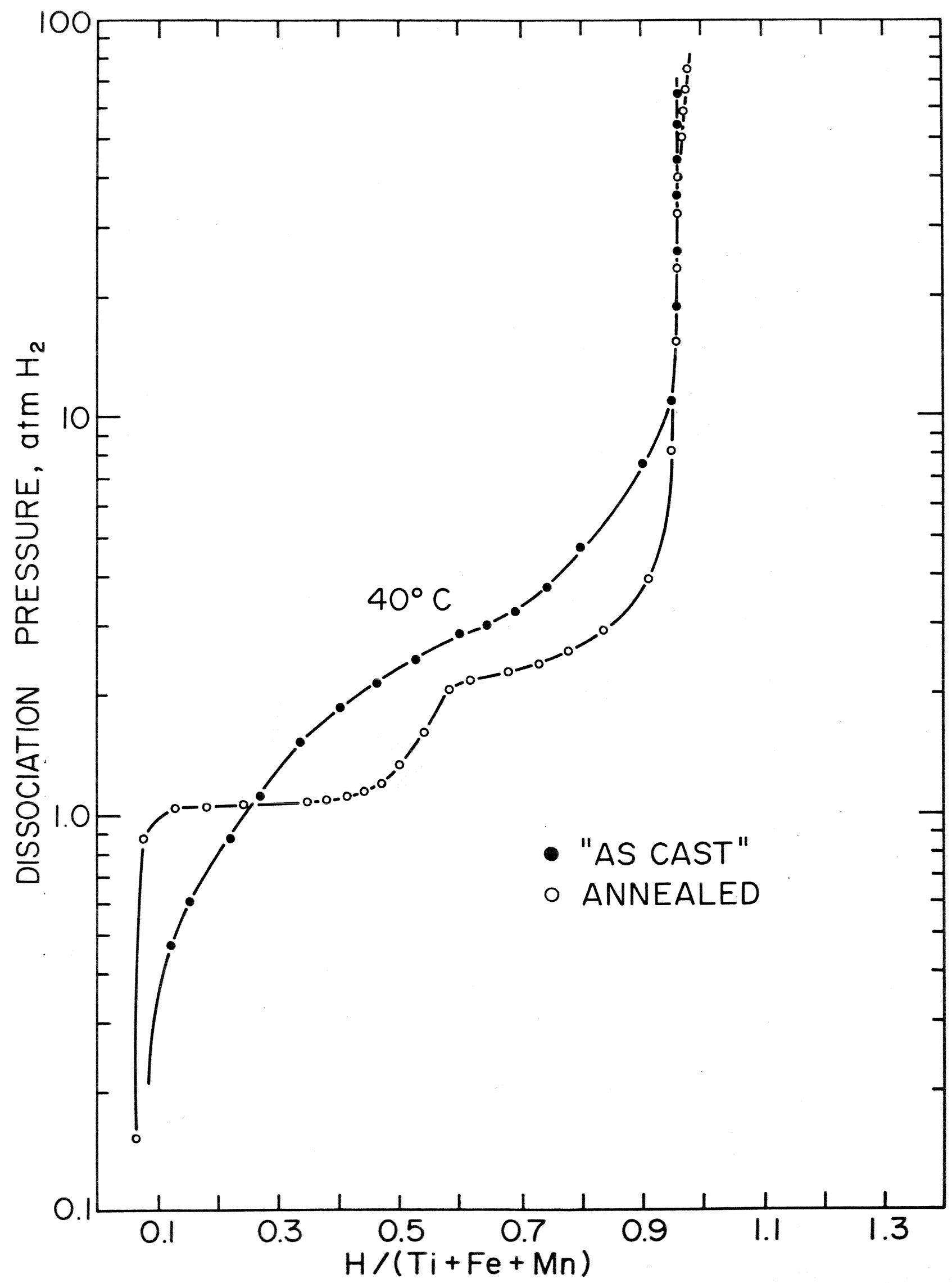

Fig. 8. A Comparison of Pressure-Composition Desorption Isotherms for Annealed and "As-Cast" TiFe $0.76^{\mathrm{Mn}} 0.13$ at $40^{\circ} \mathrm{C}$. 


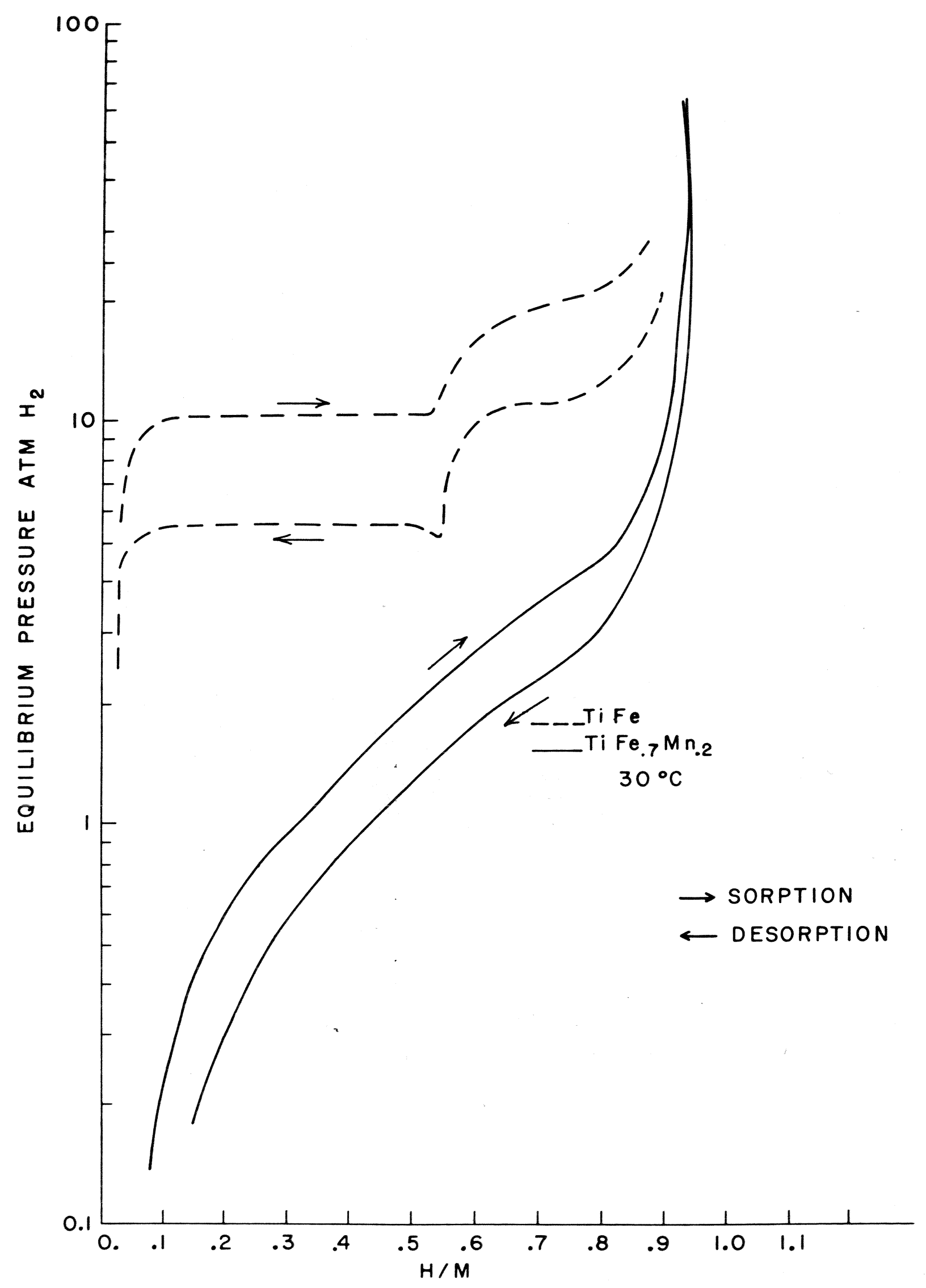

Fig. 9. Hysteresis in FeTi and $\mathrm{TiFe}_{0.7^{\mathrm{Mn}}} \mathrm{H}_{0.2}$ at $30^{\circ} \mathrm{C}$. 


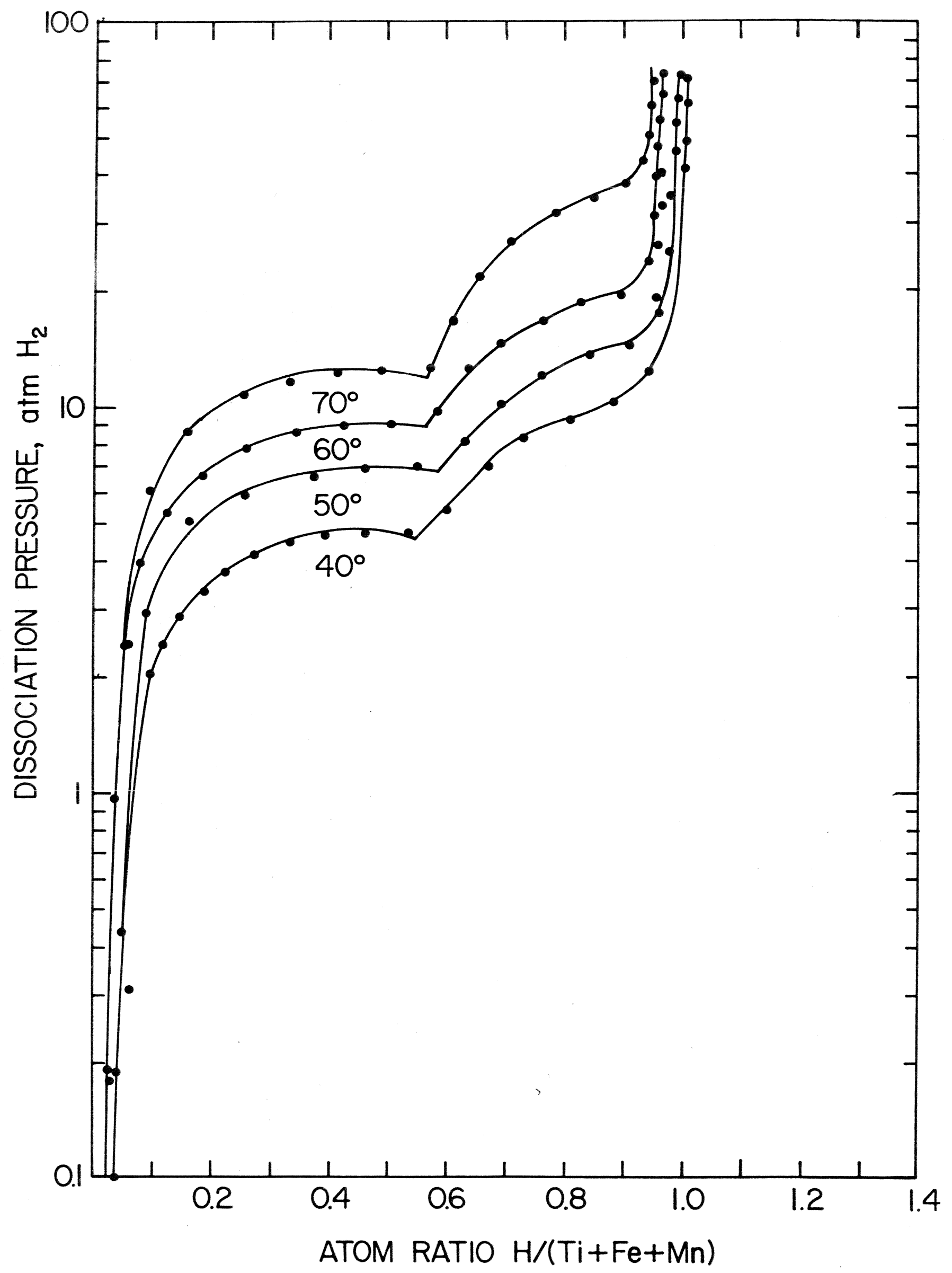

Fig. 10. Pressure-Composition Desorption Isotherms for the

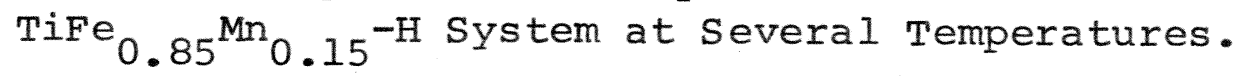




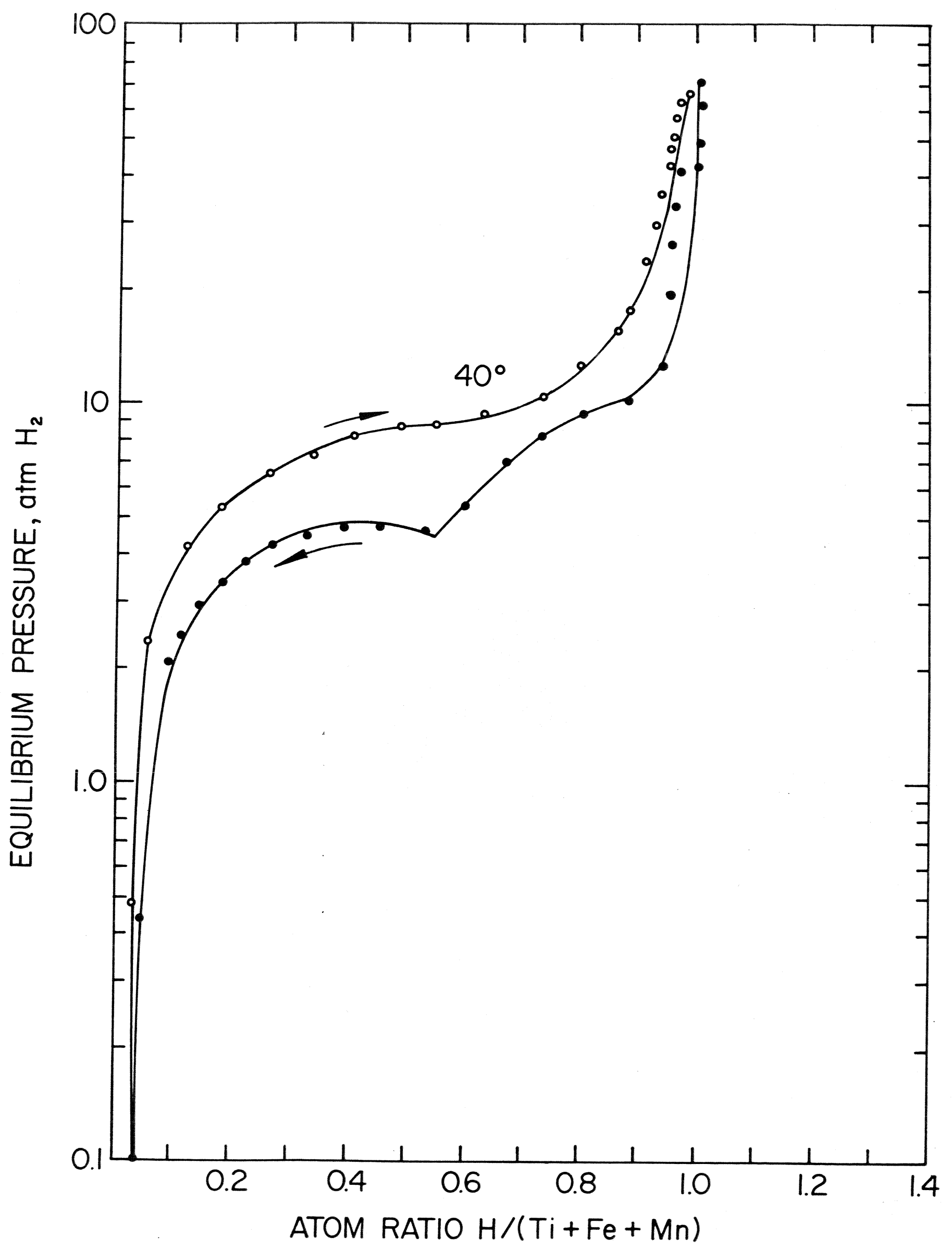

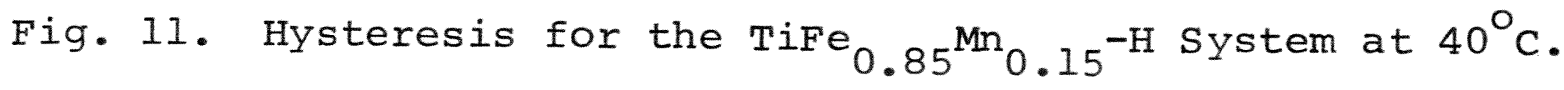

